\title{
West German release of altered bacteria causes furore
}

\section{Munich}

THE release of genetically manipulated bacteria onto a pea field in West Germany has set off a sharp debate and put scientists and public officials on the defensive.

The bacteria are of the genus Rhizobium, which adhere to the roots of leguminous plants and fix nitrogen. They were manipulated in vivo to include a transposon containing an antibiotic resistance gene intended to serve as a genetic marker. The releases, made somewhere in Bavaria in May, first came to public attention in West Germany in late July.

The experiment was carried out by Walter Klingmüller, a geneticist at the University of Bayreuth, under the auspices of the Biotechnology Action Programme of the European Economic Commission (EEC). It followed similar studies conducted at the Rothamsted Experimental Station in Britain and at the National Institute for Agricultural Research in Dijon, France.

The purpose of the experiments, said Klingmüller, was threefold: to determine how many of the bacteria survive; to determine whether any of the genetic material, that is, the transposoncontaining plasmid, is transferred from the altered Rhizobium to other bacteria; and, in the event that the plasmid is transferred, to determine whether the antibiotic resistance gene remains in the bacteria's DNA even if the plasmid itself breaks down.

According to Klingmüller, the first set of results indicate that most of the altered Rhizobium have, not surprisingly, died off. It has not yet been determined whether the transposon was transferred to other bacteria. But the furore that followed public disclosure of the experiment had more to do with the official attitude towards the release than it did with the results. In order to comply with West German regulations on genetic engineering, any experiment involving the release of "genetically manipulated organisms" must be approved by the Central Committee for Biological Safety (ZKBS), a division of the Federal Health Office.

But "genetically manipulated organisms" are defined to include only those created in vitro using recombinant DNA techniques. The Rhizobium released in Bavaria do not fall under this rubric and therefore needed no official approval.

This distinction appears nitpicking to the critics of genetic engineering, among them the Green Party and Wolf-Michael Catenhusen (Social Democrat), chairman of the Research and Technology Committee in the Bundestag (parliament).

Catenhusen chaired an Enquete Com- mission on Genetic Engineering during the last Bundestag session that recommended a five-year moratorium on any release of genetically altered organisms into the environment. That none of the authorities responsible - the ZKBS or the Research Ministry (BMFT), for example - made the experiments public is a "political snub" to the public and the Bundestag according to Catenhusen.

The Greens were also outraged that the ZKBS used the in vivo/in vitro distinction to justify the experiments, and find it incredible that the BMFT report of September 1986 stated that there have been no projects proposed to the ZKBS “in which

a proposed goal is to develop genetically manipulated organisms for later release into the environment".

Even before the West German release was announced, a Green representative to the European Parliament, Benedikt Härlin, had introduced a resolution to the EEC to place a moratorium on all releases of altered organisms into the environment. A previous draft proposal had called for regulations only on organisms manipulated using in vitro recombination.

Catenhusen is determined to introduce the subject early in the next Bundestag legislative session this autumn. The Deutsche Forschungsgemeinschaft, which funds much of West German basic research, said in May that it rejects a moratorium, although it recognizes the danger of releasing organisms that have been manipulated in vivo. Steven Dickman

\section{UK publishes report on CFCs based on old data}

\section{London}

BRITAIN's Department of the Environment (DOE) has come in for sharp criticism for its fanfare in issuing a report on chlorofluorocarbons (CFCs) and stratospheric ozone based on two-year-old data.

In the first sentence of its press release heralding the newly published report of the Stratospheric Ozone Review Group, the DOE claims that the present rate of CFC production is unlikely to lead to a reduction of the stratospheric ozone layer. But the group's report is based mainly on the findings of the assessment carried out by the US National Aeronautics and Space Administration and World Meteorological Organization in 1985. Ozone research is developing rapidly, and many scientists involved consider that assessment to be out of date.

Some scientists argue that the government should have quietly buried the report and arranged for an immediate update based on the latest findings of the role of chlorine in the formation of the Antarctic ozone hole. "It is very naughty of the DOE to dress up that report with a press release", says Dr Joe Farman of the British Antarctic Survey, a member of the Stratospheric Ozone Review Group.

The report concludes that one-dimensional models, which are subject to large uncertainties, predict that globally averaged column ozone will not be depleted at present levels of CFC emissions and other source gases. It points out that two-dimensional models predict larger decreases in ozone. The report summarizes both types of models as well as experimental evidence.

The DOE's press release also says that advice from the report allowed the government to formulate a policy on regulating CFCs based on "a sound understanding of the science". But pressure groups maintain that the government wants to use outdated research to bolster the position that there is no need for stringent regulatory controls on CFCs. Britain has been accused of dragging its feet in the international negotiations on a protocol to control emissions of CFCs to protect the ozone layer, although recently its negotiators have shown more willingness to compromise.

There are indications that countries involved in the Vienna Convention for the Protection of the Ozone Layer will finally reach agreement and sign a protocol in Montreal next month calling for an eventual 50 per cent reduction in CFC production. Farman says there is widespread agreement among scientists that an immediate 85 per cent cutback is needed just to hold present atmospheric chlorine levels constant, because chlorine is being pumped into the atmosphere six times faster than it can be removed naturally.

Antarctica's seasonal ozone hole cannot be satisfactorily explained by anything except CFCs, according to Farman (see Nature 328, 463; 1987).

The DOE points out that emissions of methane can compensate for CFCinduced ozone destruction. However, scientists argue that chemical engineering of the atmosphere is not a satisfactory solution, especially when greenhouse gases are involved.

Ozone experts are worried that if there is a critical level of chlorine in the atmosphere, it has already been surpassed in the Antarctic; they argue that if CFCs continue to be emitted, the critical levels could be surpassed in middle latitudes too.

Kathy Johnston 